\title{
Role of Adenoidectomy in Adenotonsillectomy: An Observational Study
}

\author{
S Vinayak E
}

\begin{abstract}
The present study is an observational case series study of 50 cases of patients in the age group of 5-15 years for a period of 2 years. The age range was chosen, where issue of tonsillar and adenoid hypertrophy is very common. The objective of this case series is to establish that adenoidectomy is not a requirement while performing adenotonsillectomy unless and until the patient suffers from genuine adenoid hypertrophy symptoms. Keywords: Adenoid hypertrophy, Adenoidectomy, Adenotonsillectomy.

Clinical Rhinology An International Journal (2019): 10.5005/jp-journals-10013-1360
\end{abstract}

\section{INTRODUCTION}

Tonsils and adenoids are lumps of tissue (like the "glands" that are in the neck and other parts of the body). The tonsils sit on either side of the back of the throat (pharynx). Adenoids sit where the back of the nose meets the throat. You cannot see them through the mouth without the use of special instruments. Tonsils and adenoids are usually larger in children but tend to shrink to adult proportions by the age of 8-12 years. An adenotonsillectomy is an operation to remove both the adenoids and the tonsils.

Although tonsils and adenoids are part of the infection-fighting (immune) system, they are not essential, and their removal will not cause harm to the infection-fighting system. Other parts of the infection-fighting system in the upper throat continue to function.

\section{Patient Selection}

The patients selected for this case series were suffering from symptoms of adenoiditis and chronic tonsillitis. A few of the patients with symptoms of adenoiditis were treated conservatively with nasal sprays, while few others were subjected to an on table assessment of adenoids and preoperative X-ray, and a decision was taken to tackle the adenoids; thus, now it was a matter of investigation and evaluation that is it justified doing adenoidectomy when we plan for a adenotonsillectomy.

Tonsilloadeno-resection is a common surgical procedure performed in children, this study and case series were designed to evaluate if we really require adenoidectomy while planning to do a tonsilloadeno-resection or not.

\section{Materials and Methods}

\section{Study Design}

Case series of 50 cases including those aged 5-15 years with symptoms of adenotonsillitis, including male and female patients. Male-to-female ratio is 4.2:5.8 per patient distribution according to sex ratio (Table 1 and Fig. 1).

A questionnaire was made in the local language (Kannada).

All patients were subjected to a questionnaire prior to be taken for surgery with questions based on symptoms of chronic tonsillitis namely:
Department of ENT, Pandit General Hospital, Sirsi, Karnataka, India

Corresponding Author: S Vinayak E, Department of ENT, Pandit General Hospital, Sirsi, Karnataka, India, Phone: +91 9448965059, e-mail: vinoo121071@gmail.com

How to cite this article: Vinayak ES. Role of Adenoidectomy in Adenotonsillectomy: An Observational Study. Clin Rhinol An Int J 2019;12(2 and 3):45-48.

Source of support: Nil

Conflict of interest: None

\begin{tabular}{llc} 
Table 1: Male-to-female ratio in the study \\
\hline Sex & Frequency & Percent \\
\hline Male & 21 & 42.0 \\
Female & 29 & 58.0 \\
Total & 50 & 100.0 \\
\hline
\end{tabular}

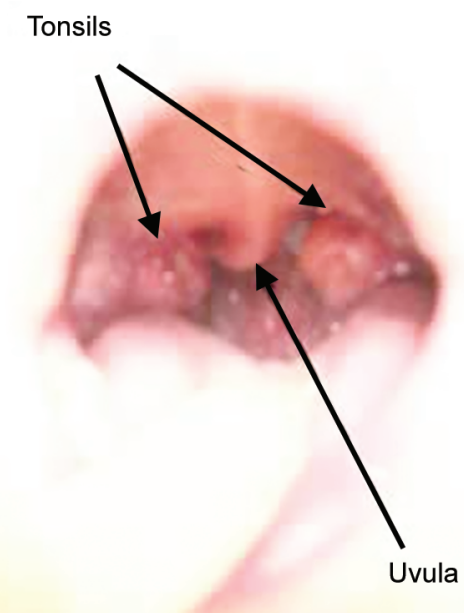

Fig. 1: Anatomical location of tonsils

() The Author(s). 2019 Open Access This article is distributed under the terms of the Creative Commons Attribution 4.0 International License (https://creativecommons.org/licenses/by-nc/4.0/), which permits unrestricted use, distribution, and non-commercial reproduction in any medium, provided you give appropriate credit to the original author(s) and the source, provide a link to the Creative Commons license, and indicate if changes were made. The Creative Commons Public Domain Dedication waiver (http://creativecommons.org/publicdomain/zero/1.0/) applies to the data made available in this article, unless otherwise stated. 


\section{Questionnaire}

- Attacks per year; attacks comprising of:
a. Odynophagia
b. Fever
c. Enlarged tonsils
d. Presence of palpable jugulodigastric lymph nodes

- Symptoms of chronic adenoiditis:
a. Mouth breathing
b. Snoring
c. Drooling of saliva
d. Symptoms related to eustachian tube obstruction
e. Acute otitis media
f. Investigation like pre op X-ray
g. Other routine investigations were done.

\section{Observation and Results (Tables 2 to 5 )}

Table 2: Age wise distribution in study

\begin{tabular}{llc}
\hline Age & Frequency & Percent \\
\hline $6-8$ & 17 & 34.0 \\
$9-11$ & 12 & 24.0 \\
$12-14$ & 18 & 36.0 \\
$>15$ & 3 & 6.0 \\
Total & 50 & 100.0 \\
\hline
\end{tabular}

Table 3: Treatment and outcome statistics

\begin{tabular}{|c|c|c|c|}
\hline \multirow[b]{2}{*}{ Treatment } & \multicolumn{2}{|c|}{ Status of the patient } & \multirow[b]{2}{*}{ Total } \\
\hline & Improved (\%) & Not improved (\%) & \\
\hline \multirow[t]{2}{*}{ Tonsillectomy } & 33 & 0 & 33 \\
\hline & 67.3 & 0.0 & 66.0 \\
\hline \multirow[t]{2}{*}{ Adenotonsilectomy } & 5 & 1 & 6 \\
\hline & 10.2 & 100.0 & 12.0 \\
\hline \multirow{2}{*}{$\begin{array}{l}\text { Conservative } \\
\text { treatment }\end{array}$} & 11 & 0 & 11 \\
\hline & 22.4 & 0.0 & 22.0 \\
\hline \multirow[t]{2}{*}{ Total } & 49 & 1 & 50 \\
\hline & 100.0 & 100.0 & 100.0 \\
\hline
\end{tabular}

Fisher's exact test-7.483, $p$ value- 0.024

Table 4: Treatment outcome

\begin{tabular}{lcc}
\hline Treatment & Frequency & Percent \\
\hline Tonsillectomy & 33 & 66.0 \\
Adenotonsilectomy & 6 & 12.0 \\
Conservative & 11 & 22.0 \\
treatment & & \\
Total & 50 & 100.0 \\
\hline
\end{tabular}

Table 5: Patient status

\begin{tabular}{lcc}
\hline Status of the patient & Frequency & Percent \\
\hline Improved & 49 & 98.0 \\
Not improved & 1 & 2.0 \\
Total & 50 & 100.0 \\
\hline
\end{tabular}

\section{Statistical Analysis}

The data were entered in Excel sheet and analyzed using SPSS version 10. The categorical data were represented using descriptive statistics, such as frequency, percentage, and graphical methods, and statistical tests like Chi-square test was applied. The level of statistical significance was set to be $<0.05$.

\section{Discussion}

Enlarged tonsils and large adenoids amounting to symptoms of obstructive sleep apnea syndrome such as snoring and mouth breathing is common in children, thus resulting in patients to undergo tonsilloadenoid-resection. Just because tonsils or adenoids are enlarged, it is not a good reason for surgical removal of tonsils and adenoids. 'Tonsilloadenoid-resection is recommended only if there is a functional problem (Figs 2 to 6 , Tables 6 to 8 ).

Tonsils are in the back of the mouth flanked by the uvula along the sides of the throat, and adenoids are located above and behind the uvula. ${ }^{1}$ Waldeyer ring ${ }^{2}$ is a ring of lymphatic tissue in the oral cavity and nasopharynx. Tonsils and adenoids are a part of this lymphatic ring. Tonsil refers to palatine tonsil bounded by the palatoglossus muscle (anterior tonsillar pillar) and the palatopharyngeus (posterior tonsillar pillar), the palatine tonsil forms the lateral aspect of the ring, and the adenoids are located in the nasopharynx to form the superior aspect of the ring, which could be seen on endoscopy and as a soft tissue mass on soft tissue $X$-ray lateral view of the nasopharynx.

Tonsils and adenoids generally regress in size with age. Although tonsils and adenoids are a part of the immune system, they are not essential, and there is no harm to the immune system if removed. ${ }^{3}$

The criteria to do a tonsillectomy or adenoidectomy was: ${ }^{4}$

- Narrowing of the airway

- Mouth breathing

- Signs of obstructive sleep apnea

- Odynophagia

- Severity of bouts as a general guideline:

a. 7 or more times an infection of the tonsils in one year

b. 5 attacks per year for 2 consecutive years

c. 3-4 attacks over 3 or more years

- Who do not respond to antibiotic treatment.

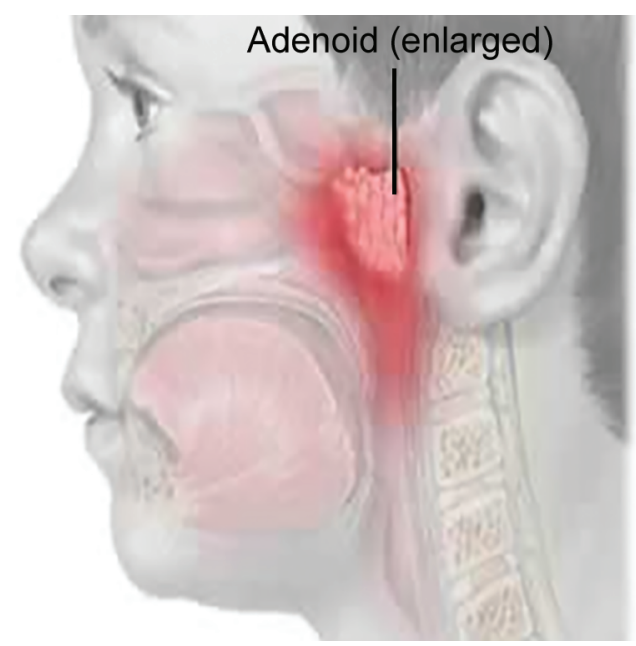

Fig. 2: Anatomical location of adenoid 


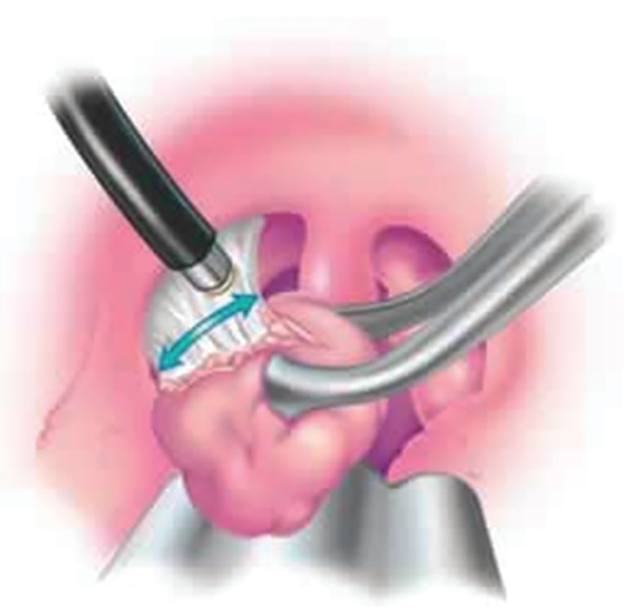

Fig. 3: Coblator being used to remove tonsil

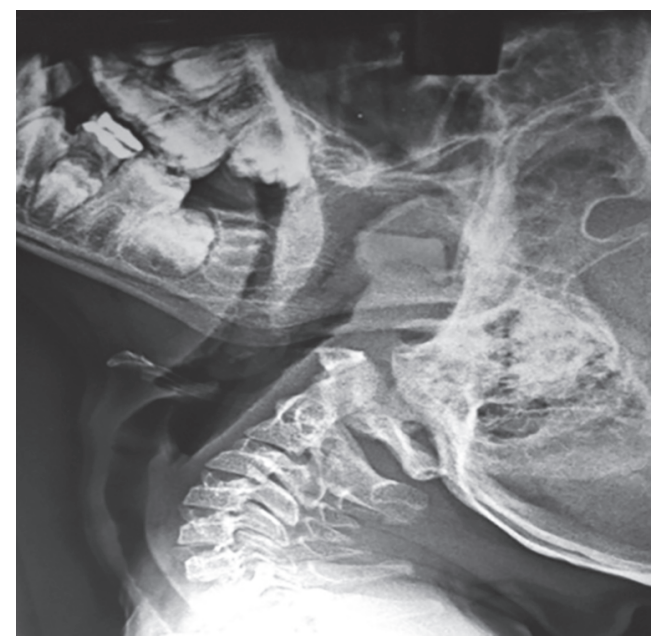

Fig. 5: Lateral view of nasopharynx soft tissue showing adenoid tissue enlargement

Table 6: Complete statistical analysis of the study based on treatment

\begin{tabular}{|c|c|c|c|}
\hline \multirow[b]{2}{*}{ Treatment } & \multicolumn{2}{|c|}{ Status of the patient } & \multirow[b]{2}{*}{ Total } \\
\hline & Improved (\%) & Not improved (\%) & \\
\hline \multirow[t]{2}{*}{ Tonsillectomy } & 33 & 0 & 33 \\
\hline & 67.3 & 0.0 & 66.0 \\
\hline \multirow[t]{2}{*}{ Adenotonsilectomy } & 5 & 1 & 6 \\
\hline & 10.2 & 100.0 & 12.0 \\
\hline \multirow{2}{*}{$\begin{array}{l}\text { Conservative } \\
\text { treatment }\end{array}$} & 11 & 0 & 11 \\
\hline & 22.4 & 0.0 & 22.0 \\
\hline \multirow[t]{2}{*}{ Total } & 49 & 1 & 50 \\
\hline & 100.0 & 100.0 & 100.0 \\
\hline
\end{tabular}

Fisher's exact test-7.483, $p$ value- 0.024

Surprisingly, in our series, the patients planned for adenoidectomy after obtaining X-ray of the soft tissue of nasopharynx (lateral view) for all patients complaining of snoring and mouth breathing, which showed significant soft tissue mass. On table prior to doing a tonsillectomy, a digital palpation was done, if the posterior end of

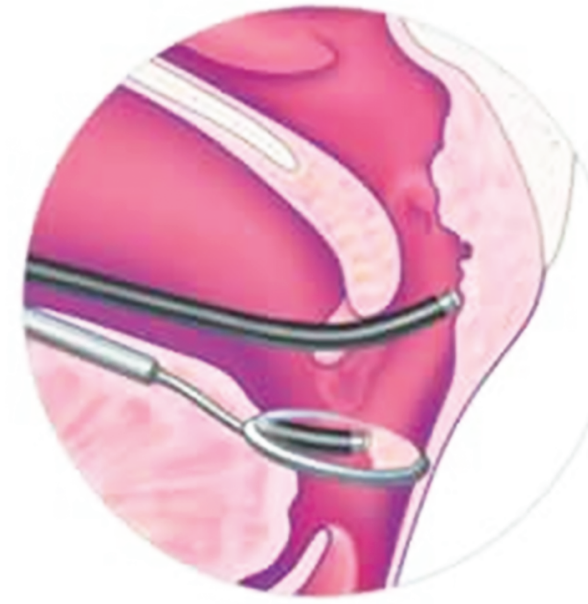

Fig. 4: Coblation

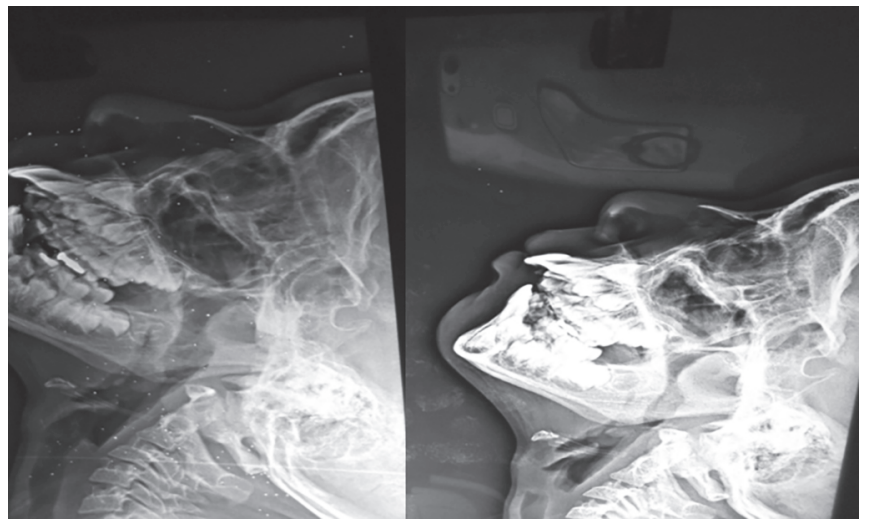

Fig. 6: X-ray of same patient showing regression of adenoid size post treatment with nasal spray

Table 7: Complete statistical analysis of the study based on age group

\begin{tabular}{llll}
\hline & \multicolumn{3}{c}{ Status of the patient } \\
\cline { 2 - 3 } Age & Improved (\%) & Not improved (\%) & Total \\
\hline $6-8$ & 17 & 0 & 8 \\
& 34.7 & 0.0 & 22.9 \\
$9-11$ & 11 & 0 & 10 \\
& 22.4 & 0.0 & 28.6 \\
$12-14$ & 18 & 1 & 14 \\
& 36.7 & 100.0 & 40.0 \\
$>15$ & 3 & 0 & 3 \\
& 6.1 & 0.0 & 8.6 \\
Total & 49 & 1 & 35 \\
& 100.0 & 100.0 & 100.0 \\
\hline
\end{tabular}

Fisher's exact test-3.72, $p$ value -0.28

the nasal septum and the eustachian tube orifice were clearly felt, then adenoidectomy was not carried forward. In our case series, most of the patients underwent tonsillectomy by dissection method using cold steel and adenoidectomy if done was done using curette with cage, no coblation or radiofrequency was used, and the use of a curette was done while doing adenoidectomy ${ }^{5}$ and/or cold steel being used to do adenoidectomy. 
Table 8: Complete statistical analysis of the study on the basis of sex ratio

\begin{tabular}{|c|c|c|c|}
\hline \multirow[b]{2}{*}{ Sex } & \multicolumn{2}{|c|}{ Status of the patient } & \multirow[b]{2}{*}{ Total } \\
\hline & Improved (\%) & Not improved (\%) & \\
\hline \multirow[t]{2}{*}{ Male } & 21 & 0 & 21 \\
\hline & 42.9 & 0.0 & 42.0 \\
\hline \multirow[t]{2}{*}{ Female } & 28 & 1 & 29 \\
\hline & 57.1 & 100.0 & 58.0 \\
\hline \multirow[t]{2}{*}{ Total } & 49 & 1 & 50 \\
\hline & 100.0 & 100.0 & 100.0 \\
\hline
\end{tabular}

Fisher's exact test- $0.739, p$ value -1.000

The advantage of such a method was the avoidance of unnecessary adenoidectomy being done, and thus avoiding injuries to structures near the adenoids like the eustachian tube orifice that could lead to middle ear problems later if the patient has no symptoms suggestive of any middle ear pathology prior to surgery. Secondly, as discussed earlier the adenoids could be preserved as it helps in the immune system. ${ }^{3}$

Patients were asked to follow-up after a week of surgery. The symptoms of nasal twang prior to surgery improved, and there was no snoring or mouth breathing which was present prior to surgery all subsided by doing merely a tonsillectomy.
Patients only having symptoms of adenoids such as snoring, mouth breathing, and no enlarged tonsils, after confirming with an $\mathrm{X}$-ray, had surprisingly improved by using nasal spray. ${ }^{4}$

\section{Conclusion}

Putting all the abovementioned points into contention, it was observed after looking into our case series outcome that there was no actual need to do an adenoidectomy when planning for a tonsilloadeno-resection. With our study and experienced outcome, we conclude no significant role of adenoidectomy in adenotonsillectomy.

\section{References}

1. Dr. Christopher Chang htpp://www.fauquiernt.net/tonsillectomy. htm.

2. Gigante J, M.D tonsillectomy \& adenoidectomy (paediatrics in review -June 2005,vol 26/issue 6).

3. Tonsillectomy and adenotonsillectomy, http://www.kidshealth.org. $\mathrm{nz} /$ tonsillectomy \& adenotonsillectomy.

4. Paediatrics \& child health division of the Royal Austrailian College of Physicians \& The Austrailian Society of Otolaryngology, Head \& Neck Surgery 2008. Indication for tonsillectomy and adenotosillectomy in children: A joint paper.

5. Adeniod Removal-Surgery Procedures and Risks-NY TIMES Health Information. 